\title{
Understanding the robustness of incidental vocabulary acquisition through reading: Qualitative insights from biolinguistics
}

\author{
D. R. Rahul ${ }^{1} \&$ R. Joseph Ponniah ${ }^{2}$ \\ ${ }^{1}$ Research Scholar, National Institute of Technology, Tiruchirappalli. ORCID: oooo-ooo2- \\ 4215-1769. Email: rahuldrnitt@gmail.com \\ ${ }^{2}$ Professor, National Institute of Technology, Tiruchirappalli. ORCID: oooo-0ooz-0618- \\ 6788. Email: joseph@nitt.edu
}

\begin{abstract}
Studies have shown the potentials of reading on the development of language. Especially, the literature on second language reading is replete with evidence that unearths the incidental acquisition of vocabulary through reading. Free and pleasurable reading, which has a marked effect on the frequency of reading, contributes significantly to the incidental acquisition of vocabulary. However, only a few studies have explored the interconnection among vocabulary acquisition, free and/or pleasure reading, and the reading frequency. To this end, this study manifests the incidental acquisition of vocabulary through reading and foregrounds the importance of free reading, reading pleasure, and reading frequency for vocabulary development. By confirming the strong correlation between reading frequency and the vocabulary test scores of the participants we attest that the reading frequency is significantly associated with free and/or pleasure reading (in our case, liking towards self-selected reading). We also theoretically contextualize and support the argument of incidental vocabulary learning through reading from a biological perspective. Given that the acquisition of any language subskill is enabled by the amalgamation of nature and environment, insights into the biological system of reading implicates a better understanding of the incidental acquisition of vocabulary through reading.
\end{abstract}

Keywords: vocabulary, reading, incidental learning, pleasure reading, biolinguistics

\section{Introduction}

Vocabulary learning has been a great deal of interest in language education. Educators and cognitive psychologists reinforce the idea that vocabulary is acquired and developed mostly through reading. Studies prove that reading is significantly correlated with vocabulary knowledge, development, and acquisition, both in first and second language (L1 and L2) (Daskalovska, 2014; Krashen, 1989; Matsuoka \& Hirsh, 2010; Pigada \& Schmitt, 2006; Ponniah, 2011). Accordingly, reading is a major contributing factor in an individual's vocabulary repertoire. Nevertheless, reading itself, along with vocabulary, is influenced by several factors like reading frequency and pleasurable reading materials. The more the learners engage in reading, the more they acquire, and vocabulary (Stanovich, 2017).

\footnotetext{
(c) AesthetixMS 2020. This Open Access article is published under a Creative Commons Attribution Non-Commercial 4.o International License (http://creativecommons.org/licenses/by-nc/4.o/), which permits non-commercial re-use, distribution, and reproduction in any medium, provided the original work is properly cited. For citation use the DOI. For commercial re-use, please contact editor@rupkatha.com.
} 
Both first and second language (L1 and L2) learners gain their vocabulary knowledge through reading. Jenkins, Stein, and Wysocki (1984) examined the learning of unfamiliar words in Li among fifth-grade children and claimed that children incidentally acquire vocabulary through reading by learning their meaning in context. In a similar vein, according to the reading hypothesis, when the L2 learners are exposed to reading in L2 they acquire vocabulary incidentally through their contextual meaning (Krashen, 2004). For instance, Ponniah (2011) demonstrated that the meaning and grammatical forms of words that the learners did not encounter earlier were incidentally acquired through reading. Zahar, Cobb, and Spada (2001) analyzed the relationship between acquisition of vocabulary and reading by focusing on word frequency and learning gains and concluded that authentic reading text is the most valuable source of word acquisition. A battery of research focusing on the contribution of reading to vocabulary acquisition insists that learners can acquire and develop their vocabulary knowledge incidentally through reading.

It is imperative to understand that free/self-selected reading is crucial for the development of language sub-skills. The learning and development of language sub-skills become uncomplicated when the input is comprehensible (Krashen, 2003). Comprehensible reading input renders satisfaction and pleasure to learners upon understanding the reading material without much strain (Krashen, 1994). In such a scenario, reading is influenced by the pleasure component and it leads to more reading. Consistent with the food pleasure hypothesis which claims the amount of food intake is based on the pleasure experienced by its taste (Witherly, 2007), the frequency of reading increases when the reading experiences are pleasurable and thereafter, more comprehensible reading is sought. As readers engage in more reading, they choose reading texts of their own choice, which they continue to read given the choice of text is comprehensible and pleasurable. Many studies adduce this claim premised on pleasure reading and free reading (which is self-selected reading (SSR) in our case). For instance, Cho and Krashen (1994) reported that adult ESL students found pleasure and enjoyed reading when they read comprehensible reading material. McQuillan (1994) stated that the students preferred reading the text of their own choice over classroom instruction. Krashen (2004) delineated several case histories that claimed the gains of self-selected reading in literacy development. Correspondingly, free reading as a crucial determining factor in the development of vocabulary is confirmed by studies that address the significance of literacy and lexical gain through SSR over the prescribed text (Lao \& Krashen, 2000; Ponniah, 2018). SSR is more effective than the instructional methods as Ponniah (2011) stated that incidental acquisition of vocabulary through reading is proficient than intentional learning. Moreover, research also confirms the frequency of reading to be increased when it is free/self-selected (Nell, 1988).

Frequency is an indispensable factor for development in every domain of cognition and behavior, especially language. The comprehensive review by Ambridge, Kidd, Rowland, and Theakston (2015) describes the ubiquity of reading frequency in language acquisition with a focus on lexis. Accordingly, the frequency of reading has a significant impact on vocabulary acquisition (Eckerth \& Tavakoli, 2012). It provides a possibility for learners to get exposed to words in different contexts and thereby incidentally learn them (Teng, 2016). Collins (2010) experimented with this aspect and found that the initial vocabulary knowledge and frequency of reading, especially, free voluntary reading, contributed to learning as the learners were frequently exposed to target words, and eventually acquired them. Similarly, Webb (2007) examined that the vocabulary learning of students increased each time when the exposure of the word increased. 
Thus, the frequency of reading, which enables the frequency of word encounter in different contexts, influences the incidental learning of vocabulary.

Vocabulary development through pleasure reading is one of the widely discussed topics in language learning. Subsequently, the pleasure factor in reading is an oft-registered aspect in the literature of reading and the minutiae of the biological dimension of reading and vocabulary gain. Understanding the process of pleasure in reading from a biological point of view is a transcendent activity about the human brain. Kringelbach, Vvust, and Geake (2008) note that very little is known about the system and process that allow us to read, understand, and extract pleasure from the text. However, it is our brain that decides an activity to be pleasurable and allows us to continue the activity. The prolongation of an activity is based on the pleasure component and expires if there is no pleasure involved. Pleasure allows readers to involve in continuous reading and even more reading their own choice of text as reported by the pleasure hypothesis (Krashen, 1994). The extension of the food pleasure hypothesis to the pleasure reading hypothesis is rational because neuroscience reveals that the neuro mechanism and brain pattern of pleasure derived from any activity is the same in its nature i.e., the pleasure of food can be applied to that of other activities as well (Kringelbach, Stein, \& van Hartevelt, 2012; Vuust \& Kringelbach, 2010). Also, it is understood that the release and functioning of dopamine as a neurotransmitter in such pleasurable activities keeps the continuation of the activity.

Though a wealth of research is focused on the development of vocabulary through reading, pleasure reading, and free reading independently, there has always been a gap in bridging the gap among these. The goal of the study is to prove that learners can incidentally acquire vocabulary through reading, especially when the reading is pleasurable, self-selected, and the frequency is high. Although reading as a comprehensible input is far more important than other factors because of its robustness SLA, it is undeniable to consider how the human brain adapts the input from the environment in the process of acquisition for the understanding of the importance of input. The biological underpinnings for language difficulties, insights into the interaction of complex genetic and environmental factors, and cognitive neuroscience allow us to consider the marriage of these biological factors with input/reading hypothesis to arrive at an exhaustive approach to address the incidental vocabulary acquisition through reading.

\section{Study}

The influence of SSR and pleasure on vocabulary development has been reported by many, however, the frequency of SSR driven by pleasure in reading that contributes to vocabulary achievement is little explored. Therefore, we would like to attempt this study consistent with the reading hypothesis by examining the participants in India where English is a second language for most and add a qualitative standpoint to it from a cognitive-biolinguistics perspective. We hypothesize that pleasure in SSR favors the frequency of SSR to result in word learning and development.

\section{Participants}

Participants of this study were 59 select people aged between 18 and 45 from the higher educational institutions in India for whom English is a second language. All the participants are familiar with English as they have completed at least one degree in English either as the medium of instruction or as the course itself. Among the participants, $44 \%$ reported that they use English more than $50 \%$ of the time and $28 \%$ use it $30-50 \%$ of the time in their daily conversation. 


\section{Methods, and Results}

This study reports a correlation analysis as it is commonly understood that correlational studies are by far most effective when it comes to identifying the relationship between variables of the constituent.

The participants were asked to take a test and answer an additional set of questions given in a questionnaire. The test had 40 questions on vocabulary that included different kinds of questions like matching the appropriate answer, tense form, etc. The questions were taken from Oxford bi free online vocabulary proficiency test and locally modified according to the need. The test scores of the participants were collected and analyzed for the reliability of the test. The Cronbach's Alpha of the test with 40 variables was slightly less than .7 and therefore one of the items from the variables was eliminated. As shown in the table below, with 39 variables, (i.e., questions) the reliability of the test was .738 using Cronbach's Alpha reliability test.

Table 1: Reliability analysis of vocabulary test

\begin{tabular}{llc}
\hline Cronbach's Alpha & $\begin{array}{l}\text { Cronbach's Alpha Based on } \\
\text { Standardized Items }\end{array}$ & N of Items \\
\hline 0.738 & 0.718 & 39 \\
\hline
\end{tabular}

\section{Results}

The vocabulary test scores of the participants were taken as the dependent variable for the correlation study.

The independent variables consist of three items related to SSR. They are whether the participants read by selecting the material in English of their own choice, how often/frequently they read the SSR material, and whether they like the reading activity when the SSR is done.

The independent variables are described below with their means and standard deviations.

1. SSR of the participants: "Do you read the English text of your own choice? (any reading materials like blog, stories, articles, newspaper, novels, poems, etc)" for which the answer choice was either No or Yes and was given values o and 1 respectively. The mean was .86 with a standard deviation of .34.

2. Frequency of SSR: "How often do you read the English text of your own choice? (any reading materials like blog, stories, articles, newspaper, novels, poems, etc)"

$\mathrm{o}=$ do not read at all

$1=$ once in a week

$2=2-3$ times a week

$3=3-5$ times a week

$4=$ almost every day

The mean response was 2.37 with a standard deviation of $1.44 .47 \%$ of the participants reported that they do SSR more than 3 times a week which indicates that they are frequent readers with neither ceiling nor floor effect. 
5 Understanding the robustness of incidental vocabulary acquisition through reading:

Qualitative insights from biolinguistics

3. Liking for SSR: Do you like reading when you read materials of your own choice? the answer choice was either No or Yes and was given values o and 1 respectively. The mean was .95 with a standard deviation of .2 indicating that the participants were highly positive about the SSR strategy.

The responses of the participants show that they engage in SSR and the frequency of the SSR is determined by their liking toward their activity and the two are correlated significantly. The table below shows the correlation between the two:

Table 2: Correlation between liking to read and frequency of SSR

\begin{tabular}{llll}
\hline & & Liking for SSR & Frequency of SSR \\
\hline \multirow{2}{*}{ Liking for SSR } & Pearson & 1 & $.275^{*}$ \\
& Correlation & & 0.035 \\
& Sig. (2-tailed) & & 59 \\
& $\mathrm{~N}$ & 59 & 1 \\
Frequency of SSR & Pearson & $.275^{*}$ & \\
& Correlation & \multicolumn{1}{c}{0.035} & 59 \\
\hline
\end{tabular}

${ }^{*}$. Correlation is significant at the 0.05 level (2-tailed).

The frequency of the SSR is significantly correlated with the vocabulary score of the participants. The dependent variables namely the SSR, frequency of the SSR, and the liking for SSR accounted for the independent variable vocabulary score are found to be correlated when analyzed using Pearson correlation values and the table is given below:

Table 3: Correlation between the variables

\begin{tabular}{|c|c|c|c|c|c|}
\hline & & $\begin{array}{l}\text { Vocabulary } \\
\text { score }\end{array}$ & SSR & $\begin{array}{l}\text { Frequency of } \\
\text { SSR }\end{array}$ & $\begin{array}{l}\text { Liking } \\
\text { for SSR }\end{array}$ \\
\hline \multirow{3}{*}{ Vocabulary score } & Pearson Correlation & 1 & 0.247 & $.353^{* *}$ & 0.107 \\
\hline & Sig. (2-tailed) & & 0.059 & 0.006 & 0.421 \\
\hline & $\mathrm{N}$ & 59 & 59 & 59 & 59 \\
\hline \multirow{3}{*}{ SSR } & Pearson Correlation & 0.247 & 1 & $.654^{* *}$ & 0.134 \\
\hline & Sig. (2-tailed) & 0.059 & & o & 0.313 \\
\hline & $\mathrm{N}$ & 59 & 59 & 59 & 59 \\
\hline \multirow{3}{*}{ Frequency of SSR } & Pearson Correlation & $.353^{* *}$ & $.654^{* *}$ & 1 & $.275^{*}$ \\
\hline & Sig. (2-tailed) & 0.006 & o & & 0.035 \\
\hline & $\mathrm{N}$ & 59 & 59 & 59 & 59 \\
\hline \multirow{2}{*}{ Liking for SSR } & Pearson Correlation & 0.107 & 0.134 & $.275^{*}$ & 1 \\
\hline & Sig. (2-tailed) & 0.421 & 0.313 & 0.035 & \\
\hline
\end{tabular}


$\mathrm{N}$

59

59

59 59

**. Correlation is significant at the o.o1 level (2-tailed).

*. Correlation is significant at the 0.05 level (2-tailed).

Table 4: Mean and Std. Deviation of all variables

\begin{tabular}{llllll}
\hline & & $\begin{array}{l}\text { Vocabulary } \\
\text { score }\end{array}$ & SSR & Frequency of SSR & Liking for SSR \\
\hline $\mathrm{N}$ & Valid & 59 & 59 & 59 & 59 \\
\cline { 2 - 6 } & Missing & $\mathrm{o}$ & $\mathrm{o}$ & $\mathrm{o}$ & $\mathrm{0}$ \\
\hline Mean & & 23.92 & .86 & 2.37 & .95 \\
\hline Std. Deviation & 4.914 & .345 & 1.449 & .222 \\
\hline
\end{tabular}

\section{Discussion}

We hypothesized that the frequency of SSR is the most important determinant of vocabulary learning/development. Vocabulary test scores, SSR, liking for SSR, and frequency of SSR were calculated. Table 1 shows the vocabulary test is reliable as the value is 0.738 according to Cronbach's Alpha reliability test. Therefore, the test scores were used to analyze the correlation with other variables. The vocabulary test score was considered as the dependent variable and the others as the independent variable, and the Pearson correlation test was calculated.

Either to learn or use words appropriately, the word must be accompanied by a context. Participants in this study appear to be frequent readers and their reading habit promotes learning and using words in different contexts. They must have learned the words incidentally through reading as the correlation between the vocabulary test score and frequency of reading is strong.

The mean and standard deviation value of SSR of participants indicate that they engage in SSR and the frequency of their SSR is correlated with their liking towards SSR. Table 2 shows the correlation between the two and is significant at .05 level confirming that the liking for SSR correlates with the quantity of reading i.e., the frequency of SSR. Table 3 proves the initial hypothesis to be true. There is a significant correlation between the frequency of SSR and the vocabulary test score of the participants. The correlation value is significant at or level indicating the frequency of SSR is strongly correlated to one's vocabulary repertoire. This validates the claim that vocabulary learning and development is catalyzed by SSR. Further, the frequency of SSR is fuelled by the liking for SSR proving the hypothesis to be true.

The ability to repeat an activity is decided by the brain based on the pleasure derived from that activity. Pleasure determines whether to continue the activity or not and is indicated in the brain by the release and function of a neurotransmitter called dopamine. In this study, the participants were engaged in SSR and the statistical value indicates that they are good readers and gain pleasure by reading. Further, it is understood that the ability to comprehend and acquire through reading depends on the capacity of genes associated with reading, language, and cognition implying the involvement of genes in reading comprehension and vocabulary development (Keenan, Betjemann, Wadsworth, Defries, \& Olsen, 2006; Olson \& Keenan, 2007). Such being the case, it can be postulated that most of these readers in the sample group may not display any abnormalities in their molecular and brain physiology if examined because of their 
frequent engagement in SSR and strong liking towards SSR. Also, the abnormal display can be overcome by the brain's nature of adaptability through continuous reading. Research on bilingualism confirms the change in the brain's anatomy can occur in this regard i.e., when a child grows to learn two languages there is a change in structural change in white matter tracts in the brain, pointing that the brain wiring can be improved upon learning (Li, Legault, \& Litcofsky, 2014).

The cognitive linguistics point of view reinforces the understanding of the intricacies involved in the process of vocabulary acquisition through reading. Though it is understood that reading is the input for vocabulary development, the simple exposure of words does not completely aid the process (Huckin \& Coady, 1999). The exposure along with previous knowledge i.e., schema, experience, and cognition complement the process of vocabulary acquisition. Jensen (1980) proclaimed that intelligence plays a key role in children with regards to their word learning suggesting that the acquisition is not only based on the word encounter but also because of the ability to comprehend contextual meanings. The cognitive-linguistic subprocesses like selective encoding, selective combination, and selective comparison bolster active vocabulary building processes as they involve different cognitive strategies and skills like using previous knowledge, eliminating irrelevant associations, relating meaning using available knowledge, memory, etc (Sternberg, 1987). The involvement of these aspects in the development of an individual's vocabulary repertoire permits us to consider the neuroscience of reading and vocabulary acquisition more closely.

Cognitive neuroscience affirms that our brain uses sensory and sensorimotor experiences to learn words (Macedonia, 2015). These experiences of an individual are assorted in different brain areas while learning words. The brain areas that deal with language (Friederici, 2011), cognitive control (Abutalebi, 2008), semantic processing (Binder \& Desai, 2011), multisensory integration (Seghier, 2012), memory (McClelland, McNaughton, \& O'Reilly, 1995), etc. are found to be responsible for the process of word learning. The auditory cortices store the sound when a word is read (Dubois, Poeppel, \& Pelli, 2013), and the fusiform gyrus stores the sequence of letters the word contains (McCandliss, Cohen, \& Dehaene, 2003). If there are any sensory experiences associated with the word, the piriform cortex, and the anterior insula saves them (BarrósLoscertales et al., 2012; González et al., 2006). The motor cortex and the visual and motor regions are activated when the word is written down (Yuan \& Brown, 2015). These brain areas dealing with the sensorimotor experience of reading/encountering a word portray the complex behavioral neuroscience of vocabulary acquisition.

How one learns affect the cognitive process. For example, Takashima, Bakker, van Hell, Janzen, \& McQueen (2014) observed that learning words through picture association i.e., if she is a visual learner, the memory of the learner is affected. Moreover, in L2, if the association is with gestures, word retention is affected in both long and short-term memory (Macedonia, 2014; Macedonia, Müller, \& Friederici, 2011). Gesture association of words includes both motor and sensory experiences, allowing the brain to create a complex network and has a high impact on word retention through memory. It can be observed by the way children learn words in their mother tongue. They do not learn only by listening or only by seeing but associating as many sensorimotor experiences with the word as possible. This allows us to presume that participants of this study must have engaged in different such experiences through their frequent encounters of words in different contexts as they were frequent readers. Moreover, the differences in learning performances depend on learning styles. For instance, Kapantzoglou, Restrepo, Gray, and 
Thompson (2015) confirmed that phonological working memory of word learning is based on the individual's learning style of words.

It is understood that individuals display a variety of learning styles in learning words. This allows us to postulate the dominance of the structure and function of certain brain areas over others while learning a word. For example, if a learner is a kinaesthetic learner, the piriform cortex and the anterior insula will be engaged slightly more than the other brain areas. Moreover, the learning of a new word or the revival of words is known to engage in complex networks of different brain areas (McClelland, 1985). Likewise, given the fact that the individual learning styles are different, knowledge on what provides these individual differences among people is necessary for a comprehensive understanding of the process of vocabulary learning. Interestingly, the learning styles are reflected both by the genetic and environmental influences on the individuals.

Brain areas monitoring an individual's behavior are universal, but their structure and functions differ based on the molecular biology of the individuals. Genetics research provides knowledge on the impact of genes and their variants in one's brain development. But what relevance does genetics relate to language development, reading, and vocabulary? The relevance of genetics in the process of vocabulary development through reading is understood by the role of genes in language, reading, and cognition. Recent evidence from the studies on language disorders proves that genes are responsible for language. Particularly, dyslexia or reading disorder shows the association of genes like $\mathrm{DYX}_{1} \mathrm{C}_{1}$ (Mascheretti et al., 2013), ROBO1 (Bates et al., 2011), $\mathrm{DCDC}_{2}$ (Deffenbacher et al., 2004), etc. The initial identification of FOXP2 associated with an inherited speech-language disorder depicts the inability to repeat words because of the gene mutation (Lai, Fisher, Hurst, Vargha-Khadem, \& Monaco, 2001). Results of this kind acknowledge that abnormality in genes related to language, cognition, or reading will hinder the learningacquisition process by altering the brain's physiology given the vital role of neuro mechanism in word learning through reading (Sriganesh, Rahul, \& Ponniah, 2018).

\section{Limitations and Conclusion}

Lack of data for retention of words over a period of time is a possible flaw in most of the crosssectional studies that are in line with vocabulary development through reading because most of them concentrate on immediate post-test after reading. This allows learners to retain words that are fresh in their minds. Whereas, this study is not of that kind as it employed a vocabulary test without any controlled reading exposure and the test scores were considered along with the survey for this study. This means that words are learned by the learners through SSR and their meanings are retained over time, eliminating a possible flaw of the study.

It is safe only to assume that the SSR and frequent reading allowed the learners to encounter words in different contexts that help them in acquiring the various levels of word knowledge. Nevertheless, the frequency of reading does not limit its effect in incidental word learning as the data shows a strong correlation between the test score and the frequency of reading. The sensory/sensorimotor experiences of the learners during word encounter at the time of the vocabulary test was not recorded. This shows that the activation of the brain area was not monitored in order to compound the validity of vocabulary gains through reading and neural activation. Further, the empirical evidence of the biological argument of this study stays a limitation as the facility to examine the neurological and molecular physiology for vocabulary development of individuals through reading is insufficient/limited and provides scope for future research in this perspective. 
9 Understanding the robustness of incidental vocabulary acquisition through reading:

Qualitative insights from biolinguistics

With the existence of differences in vocabulary learning styles, which is, by and large, based on the cognitive psychology and neuro-molecular physiology, it is unfortunate that these differences are not catered in the educational front, despite research evidence on genetics and educational attainment (Cesarini \& Visscher, 2017; Rietveld et al., 2013). Although the concerns of educational psychology encourage theorists and language educators to seek and adopt effective methods of vocabulary instruction, a basic understanding of cognitive neuroscience and biolinguistics would permit them to enhance learners' vocabulary acquisition.

\section{References}

Abutalebi, J. (2008). Neural aspects of second language representation and language control. Acta Psychologica, 128(3), 466-478.

Ambridge, B., Kidd, E., Rowland, C. F., \& Theakston, A. L. (2015). The ubiquity of frequency effects in first language acquisition. Journal of Child Language, 42(2), 239-273.

Barrós-Loscertales, A., González, J., Pulvermüller, F., Ventura-Campos, N., Bustamante, J. C., Costumero, V., ... Ávila, C. (2012). Reading salt activates gustatory brain regions: FMRI evidence for semantic grounding in a novel sensory modality. Cerebral Cortex, 22(11), 2554-2563.

Bates, T. C., Luciano, M., Medland, S. E., Montgomery, G. W., Wright, M. J., \& Martin, N. G. (2011). Genetic variance in a component of the language acquisition device: ROBO1 polymorphisms associated with phonological buffer deficits. Behavior Genetics, $41(1)$, 50-57.

Binder, J. R., \& Desai, R. H. (2011). The neurobiology of semantic memory. Trends in Cognitive Sciences, 15(11), 527-536.

Cesarini, D., \& Visscher, P. M. (2017). Genetics and educational attainment. Npj Science of Learning, 2, 4.

Cho, K. S., \& Krashen, S. (1994). Acquisition of vocabulary from the Sweet Valley Kids series: Adult ESL acquisition. Journal of Reading, 37(8), 662-667.

Collins, M. F. (2010). ELL preschoolers' English vocabulary acquisition from storybook reading. Early Childhood Research Quarterly, 25(1), 84-97.

Daskalovska, N. (2014). Reading and vocabulary acquisition. The International Journal of Foreign Language Teaching, 9(2), 2-8.

Deffenbacher, K., Kenyon, J., Hoover, D., Olson, R., Pennington, B., DeFries, J., \& Smith, S. (2004). Refinement of the 6p21.3 quantitative trait locus influencing dyslexia: linkage and association analyses. Human Genetics, 115(2), 128-138.

Dubois, M., Poeppel, D., \& Pelli, D. G. (2013). Seeing and Hearing a Word: Combining Eye and Ear Is More Efficient than Combining the Parts of a Word. PLoS One, 8(5), e64803.

Eckerth, J., \& Tavakoli, P. (2012). The effects of word exposure frequency and elaboration of word processing on incidental L2 vocabulary acquisition through reading. Language Teaching Research, 16(2), 227-252. 
Friederici, A. D. (2011). The Brain Basis of Language Processing: From Structure to Function. Physiological Reviews, 91(4), 1357-1392.

González, J., Barros-Loscertales, A., Pulvermüller, F., Meseguer, V., Sanjuán, A., Belloch, V., \& Ávila, C. (2006). Reading cinnamon activates olfactory brain regions. NeuroImage, 32(2), 906-912.

Huckin, T., \& Coady, J. (1999). Incidental acquisition in a second language: A review. Studies in Second Language Acquisition, 21(2), 181-193.

Jenkins, J. R., Stein, M. L., \& Wysocki, K. (1984). Learning vocabulary through reading. American Educational Research Journal, 21(4), 767-787.

Jensen, A. R. (1980). Bias in Mental Testing. New York: Free Press.

Kapantzoglou, M., Restrepo, M. A., Gray, S., \& Thompson, M. S. (2015). Language ability groups in bilingual children: A latent profile analysis. Journal of Speech, Language, and Hearing Research, 58(5), 1549-1562.

Keenan, J. M., Betjemann, R. S., Wadsworth, S., Defries, J., \& Olsen, R. K. (2006). Genetic and environmental influences on reading and listening comprehension. Journal Of Research In Reading, 29(1), 75-91.

Krashen, S. (1989). We acquire vocabulary and spelling by reading: Additional evidence for the input hypothesis. The Modern Language Journal, 73(4), 440-464.

Krashen, S. (1994). The pleasure hypothesis. In J. Alatis (Ed.), Georgetown University round table on languages and linguistics (pp. 299-322). Washington, DC: Georgetown University Press.

Krashen, S. (2003). Explorations in Language Acquisition and Use: The Taipei Lectures. Portsmouth, NH: Heinemann.

Krashen, S. (2004). The power of reading: Insights from the research (Second Edi). Portsmouth: Libraries Unlimited.

Kringelbach, M. L., Stein, A., \& van Hartevelt, T. J. (2012). The functional human neuroanatomy of food pleasure cycles. Physiology and Behavior, 106(3), 307-316.

Kringelbach, M. L., Vuust, P., \& Geake, J. (2008). The pleasure of reading. Interdisciplinary science reviews, 33(4), 321-335.

Lai, C. S., Fisher, S. E., Hurst, J. A., Vargha-Khadem, F., \& Monaco, A. P. (2001). A forkhead- domain gene is mutated in a severe speech and language disorder. Nature, 413, 519-523.

Lao, C. Y., \& Krashen, S. (200o). The impact of popular literature study on literacy development in EFL: More evidence for the power of reading. System, 28(2), 261-270.

Li, P., Legault, J., \& Litcofsky, K. A. (2014). Neuroplasticity as a function of second language learning: Anatomical changes in the human brain. Cortex, 58(1-2), 301-324.

Macedonia, M. (2014). Bringing back the body into the mind: Gestures enhance word learning in foreign language. Frontiers in Psychology, 5(1467). 
Macedonia, M. (2015). Learning styles and vocabulary acquisition in second language: How the brain learns. Frontiers in Psychology, 6(1800).

Macedonia, M., Müller, K., \& Friederici, A. D. (2011). The impact of iconic gestures on foreign language word learning and its neural substrate. Human Brain Mapping, 32(6), 982-998.

Mascheretti, S., Bureau, A., Battaglia, M., Simone, D., Quadrelli, E., Croteau, J., ... Marino, C. (2013). An assessment of gene-by-environment interactions in developmental dyslexia-related phenotypes. Genes, Brain and Behavior, 12(1), 47-55.

Matsuoka, W., \& Hirsh, D. (2010). Vocabulary learning through reading : Does an ELT course book provide good opportunities? Reading in a Foreign Language, 22(1), 56-70.

McCandliss, B. D., Cohen, L., \& Dehaene, S. (2003). The visual word form area: Expertise for reading in the fusiform gyrus. Trends in Cognitive Sciences, 7(7), 293-299.

McClelland, J. L. (1985). Distributed models of cognitive processes. Applications to learning and memory. Annals of the New York Academy of Sciences, 444(1), 1-9.

McClelland, J. L., McNaughton, B. L., \& O’Reilly, R. C. (1995). Why there are complementary learning systems in the hippocampus and neocortex: Insights from the successes and failures of connectionist models of learning and memory. Psychological Review, 102(3), 419-457.

McQuillan, J. (1994). Reading versus Grammar: What Students Think Is Pleasurable and Beneficial for Language Acquisition. Applied Language Learning, 5(2), 95-100.

Nell, V. (1988). The Psychology of Reading for Pleasure: Needs and Gratifications. Reading Research Quarterly, 23(1), 6-50.

Olson, R., \& Keenan, J. (2007). Genetic and environmental influences on vocabulary and reading development. Scientific Studies of Reading, 20(1-2), 51-75.

Pigada, M., \& Schmitt, N. (2006). Vocabulary acquisition from extensive reading : A case study. Reading in a Foreign Language, $18(1), 1-28$.

Ponniah, R. J. (2011). Incidental Acquisition of Vocabulary by Reading. The Reading Matrix, 11(2), 135-139.

Ponniah, R. J. (2018). First-Language Reading Promotes Second-Language Reading and Acquisition: Towards a Biolinguistic Approach. In R. J. Ponniah \& S. Venkatesan (Eds.), The Idea and Practice of Reading (pp. 113-124). Singapore: Springer.

Rietveld, C. a, Medland, S. E., Derringer, J., Yang, J., Esko, T., Martin, N. W., ... Boatman, J. A. (2013). GWAS of 126,559 Individuals Identifies Genetic Variants Associated with Educational Attainment. Science, 340(6139), 1467-1471.

Seghier, M. L. (2012). The angular gyrus: Multiple functions and multiple subdivisions. Neuroscientist, 19(1), $43-61$.

Sriganesh, R., Rahul, D. R., \& Ponniah, R. J. (2018). Genetics of Reading Ability and Its Role in Solving Reading Difficulties. In R. J. Ponniah \& S. Venkatesan (Eds.), The Idea and Practice of Reading (pp. 125- 
139). Singapore: Springer.

Stanovich, K. E. (2017). Matthew Effects in Reading : Some Consequences of Individual Differences in the Acquisition of Literacy. Journal of Education, 189(1-2), 23-55.

Sternberg, R. J. (1987). Most vocabulary is learned from context. In M. G. McKeown \& M. E. Curtis (Eds.), The nature of vocabulary acquisition (pp. 89-105). Hillsdale, NJ, US: Lawrence Erlbaum Associates, Inc.

Takashima, A., Bakker, I., van Hell, J. G., Janzen, G., \& McQueen, J. M. (2014). Richness of information about novel words influences how episodic and semantic memory networks interact during lexicalization. NeuroImage, $84,265^{-278}$.

Teng, F. (2016). The effects of context and word exposure frequency on incidental vocabulary acquisition and retention through reading. Language Learning Journal, 1-14.

Vuust, P., \& Kringelbach, M. (2010). The pleasure of music. In M. Kringelbach \& K. Berridge (Eds.), Pleasures of the Brain (pp. 255-269). Oxford, UK: Oxford University Press.

Webb, S. (2007). The effects of repetition on vocabulary knowledge. Applied Linguistics, 28(1), 46-65.

Witherly, S. A. (2007). Why humans like junk food. Lincoln, NE: iUniverse Inc. Publishing.

Yuan, Y., \& Brown, S. (2015). Drawing and writing: An ALE meta-analysis of sensorimotor activations. Brain and Cognition, 98, 15-26.

Zahar, R., Cobb, T., \& Spada, N. (2001). Acquiring Vocabulary through Reading: Effects of Frequency and Contextual Richness. Canadian Modern Language Review, 57(4), 541-572.

D. R. Rahul is a Research Scholar in the Department of Humanities and Social Sciences at the National Institute of Technology Tiruchirappalli, India. His research interests and publications span SLA, Reading, Applied Linguistics, and Biolinguistics. His articles are published in journals that are indexed in Web of Science, Scopus, etc.

Dr. R. Joseph Ponniah is a Professor of English in the Department of Humanities and Social Sciences at the National Institute of Technology, Tiruchirappalli. His current research and teaching interest include Biolinguistics, Reading, English Language Teaching, and Second Language Acquisition. He has widely published in peer-reviewed international journals. 